\title{
SEROLOGICAL AND MOLECULAR DIVERSITY OF HUMAN ROTAVIRUS IN SÃO PAULO, BRAZIL
}

\author{
Veridiana Munford ${ }^{1}$; Eloisa Correia Souza ${ }^{2}$; Thabata Alessandra Ramos Caruzo ${ }^{1}$; Marina Baquerizo Martinez ${ }^{2,3}$; \\ Maria Lúcia Rácz ${ }^{1 *}$
}

${ }^{1}$ Departamento de Microbiologia, Instituto de Ciências Biomédicas, Universidade de São Paulo, São Paulo, SP, Brasil; ${ }^{2}$ Hospital Universitário, Universidade de São Paulo, SP, Brasil; ${ }^{3}$ Faculdade de Ciências Farmaceuticas, Universidade de São Paulo, São Paulo, SP, Brasil

Submitted: January 05, 2007; Returned to authors for corrections: May 05, 2007; Approved: July 16, 2007

\begin{abstract}
From a total of 187 fecal samples from children with ages between 0 and 5 years, collected in the Hospital Universitário -USP, Brazil, from 1994 to 1996, 54 (28.9\%) were positive for rotavirus. Positive samples were characterized by electropherotyping, subgrouping, G serotype and genotype and P genotype. Rotavirus electropherotypes were characterized in four different long genome patterns (38.9\%), one short genome pattern $(34.0 \%)$ and $18.0 \%$ were characterized as an unusual pattern. Subgroup I was found in $38.9 \%$ strains, subgroup II in 50.0\% and 7.7\% was subgroup nonI-nonII. For G serotypes, G2 was found in 59.3\%, G1 was identified in $33.3 \%$ of strains, two samples showed mixtures of $\mathrm{G} 1+\mathrm{G} 2$ and one sample was $\mathrm{G} 1+\mathrm{G} 3$. Ten samples characterized as serotype G2 showed a long eletropherotype. Genotype G2 was the most frequently and was found in 37 $(44.0 \%)$ samples (23 samples as a single genotype and 14 as mixtures of genotypes). G1 was found in 15 samples. G3 and G4 was detected mainly in mixtures of genotypes and G5, G6 and G9 were identified only in mixtures. A total of $20(38.5 \%)$ samples were characterized as $\mathrm{G}$ genotype mixtures and P mixtures were found in $16(29.6 \%)$ samples. P[4] was found in 55.6\% of samples, P[8] in 51.9\% and P[6-M37 like] in 22.3\% of cases. P[6Gottfried like] and P[11] were detected only in mixtures. One sample with G6 specificity, mixed with a G2 rotavirus and a P[11] strain, mixed with P[4] and P[8] strain was described for the first time in Latin America.
\end{abstract}

Key words: rotavirus, gastroenteritis, PCR, serotypes, genotypes

\section{INTRODUCTION}

Group A rotavirus is the major cause of acute gastroenteritis in developed and developing countries and around 125 million cases of rotaviruses occur worldwide annually, resulting in 500 to 600,000 deaths $(17,43)$. In Brazil, the frequency of group A rotavirus infection was found to be between 12 and $42 \%$ $(7,8,25,38)$ and about 80.000 children are hospitalized for the infection (25).

Rotaviruses are member of the family Reoviridae and the genome consists of 11 segments of double stranded RNA, surrounded by three separate shells. The inner capsid (intermediate layer) is constituted of VP6 protein and its antigenicity is used to characterize seven different groups of rotavirus, A to G. Within group A the same protein characterizes four subgroups: I, II, I+II and nonI-nonII $(24,27)$. The outer capsid consists of VP7 and VP4 proteins, which form the basis of the present dual classification system for G (VP7) and P (VP4) types. The VP7 protein, expressing the major neutralization antigen, is characterized by serological and molecular techniques in $15 \mathrm{G}$ types with a good correlation for the serological and genomic classifications (24). VP4 correlation on serological and genomic classifications is difficult and till now there are $15 \mathrm{P}$ serotypes and $27 \mathrm{P}$ genotypes (29).

The frequency of group A rotavirus infections varies according to different geographical areas, years and on different

*Corresponding author: Departamento de Microbiologia, Instituto de Ciências Biomédicas, Universidade de São Paulo, Av. Prof. Lineu Prestes, 1374, São Paulo, SP, 05508-900, Brazil. Phone: 55-11-3091-7292. Fax: 55-11-3091-7354. Email: mlracz@usp.br 
seasons. Surveys around the globe indicates that G1P[8], G2P[4], $\mathrm{G} 3 \mathrm{P}[8]$ and G4P[8] are the most common $\mathrm{G}$ and $\mathrm{P}$ types combinations $(24,38,40)$. However, recently, genotypes G5, G8, G9, G11 and G12, and/or new combinations of G and P were identified in Latin America and in other parts of the world $(10,38,41)$.

The rotavirus vaccine strategy is based on the need for a vaccine candidate that provides protection against common rotavirus serotypes $(15,24)$. Thus, surveillance studies of rotavirus strains are very important before and after any vaccination programs.

The objectives of this study, was to provide further information on rotavirus strains by electropherotyping, subgroup, G serotypes and $G$ and $P$ genotypes characterization in São Paulo, Brazil.

\section{MATERIALS AND METHODS}

Sample collection: A total of 187 fecal samples from children with ages ranging from 0 to 5 years, collected in the ambulatory of Hospital Universitário (HU-USP) in São Paulo, Brazil, between March 1994 and February 1996 were tested. Of these samples, 157 were collected from children with acute diarrhea and 30 from children without diarrhea, as control. Samples were stored frozen $\left(-20^{\circ} \mathrm{C}\right)$ until analysis. This study was approved by the ethical committee of the Institute of Biomedical Sciences/ University of São Paulo.

Rotavirus strains: Reference rotavirus strains RV-A/ RV4(G1P1A[8]), RV-A/DS1(G2P1B[4]), SiRV-A/SA11(G3P5B[2]), RV-A/ST3(G4P2A[6]), PoRV-A/OSU(G5P9[7]), PoRV-A/ $\mathrm{YM}(\mathrm{G} 11 \mathrm{P} 9[7]), \mathrm{BoRV}-\mathrm{A} / \mathrm{NCDV}(\mathrm{G} 6 \mathrm{P} 6[1]), \mathrm{BoRV}-\mathrm{A} / \mathrm{UK}(\mathrm{G} 6 \mathrm{P} 7[5])$, BoRV-A/B223(G10P8[11]), and BoRV-A/678(G8P7[5]) used in this study were kindly provided by Dr. David Snodgrass, (Moredun Research Institute, Edinburgh, Scotland) and by Dr. Enzo Palombo, (WHO Collaborating Center for Research on Human Rotaviruses, Royal Children's Hospital, Melbourne, Australia). These strains were cultivated in MA104 cells (36).

Preparation of fecal suspensions: Fecal suspensions $20 \%$ $\left(\mathrm{w} / \mathrm{v}\right.$ ) were prepared in Tris/calcium buffer (Tris/HCl $0.1 \mathrm{M} ; \mathrm{CaCl}_{2}$ $1.5 \mathrm{mM}$; pH 7.3), as described by Rácz et al., 1993 (36). Supernatants were stored at $-20^{\circ} \mathrm{C}$ until analyzed.

Enzyme immunoassay for rotavirus detection and group characterization: Fecal suspensions were screened by an enzyme immunosorbent assay kit (EIARA) produced by Fundação Oswaldo Cruz, Bio- Manguinhos- RJ for detection of rotavirus A and adenovirus (32).

Polyacrylamide gel electrophoresis (PAGE): All samples were analyzed by PAGE, according to Pereira et al., 1983 and Herring et al. 1982 (22,33). The double-stranded RNA genome was extracted from fecal samples using a standard phenolchloroform extraction method, followed by ethanol precipitation.

Subgroup and serotype characterization: The VP6 subgroup (SG) specificity of the rotavirus-positive samples were determined by a double antibody sandwich enzyme immunoassay described previously (36). Monoclonal antibodies (MAbs) anti-group A rotavirus were kindly provided by Dr. T.H. Flewett (East Birmingham Hospital, Birmingham, UK). MAbs anti-subgroup I (MAb-255/60) and anti-subgroup II (MAb-631/9) were produced by Greenberg et al. (21); additional anti-subgroup I (MAb-4B5 8) was produced and provided by Liprandi et al. (27). Commercial MAbs against serotypes G1, G2, G3 and G4 (Serotec Rota-MA, Japan) were used for serotype characterization. All MAbs were used as detecting antibodies.

RT-PCR genotyping: All rotavirus group A positive fecal samples were genotyped for VP7 (G) and VP4 (P) by reverse transcription semi-nested multiplex polymerase chain reaction (RT-PCR) as described by Das et al. (12), Gentsch et al. (14) and Gouvea et al. $(18,19)$. This combined typing scheme was designed to detect VP7 genotypes G1, G2, G3, G4, and G9 (12); G5, G6, G8, G10 and G11 (18).

For VP4 genotyping, second amplification was done with specific primers to VP4 genotypes $\mathrm{P}[4], \mathrm{P} 2 \mathrm{~A}[6], \mathrm{P}[8], \mathrm{P}[9]$ and $\mathrm{P}[10]$ (14); $\mathrm{P}[1], \mathrm{P}[5], \mathrm{P} 2 \mathrm{~B}[6], \mathrm{P}[7]$ and $\mathrm{P}[11]$ (19).

Viral double-stranded genomic RNA (dsRNA) was extracted from $300 \mu \mathrm{L}$ of $20 \%$ (w/v) fecal suspensions using TRIzoL ${ }^{\circledR}$ Reagent (Invitrogen, cat. $\mathrm{N}^{\circ} 15596$ ), according to the manufacturer's protocol. dsRNA suspensions were stored at $20^{\circ} \mathrm{C}$ until tested.

The amplification products were analyzed by gel electrophoresis on $1.5 \%$ agarose, containing ethidium bromide $(10 \mathrm{mg} / \mathrm{mL}$ ), and visualized under UV light. The G and P genotypes of the samples were determined by comparing the size of second-round PCR products with the prototype strains.

All mixtures of genotypes identified with the pool of primers were tested with individual primers for the identified genotypes.

The processes were performed in four separate rooms to avoid cross contamination of samples and RT-PCR reactions were performed with viral RNA extracted from reference strains as positive controls and water as negative control (11).

\section{RESULTS}

Rotavirus antigen was detected in 54 (28.9\%) of 187 stool specimens. All positive rotavirus samples were from children with gastroenteritis. From 111 samples for which age of the children was available, the highest percentage of positive samples was found in children aged 7 to 12 months (37.1\%), followed by children aged 2 to 6 months $31.0 \%$ (Table 1). Detection of rotavirus on summer months (December-February) was very low and a peak of rotavirus incidence was observed during winter months (June-August) on both years (Fig. 1).

PAGE was performed on all samples to examine the genomic diversity of the dsRNA of the strains and to identify non-A rotaviruses. Only group A rotavirus were detected and 
electropherotypes were characterized in 50 (92.6\%) samples. Four different "long" profiles were found in 24 (48.4\%) samples and 17 (34.0\%) strains showed one unique "short" profile. Nine samples $(18.0 \%)$ were characterized as an unusual pattern, with the $10^{\text {th }}$ and $11^{\text {th }}$ segments migrating closer than in "short" electropherotypes. (Table 2, Fig. 2). In three samples, more than 11 dsRNA segments were found, suggesting the presence of dual infections with more than one strain of rotavirus, all with "long" electropherotypes. Fig. 2 showed some representative electropherotypes (lanes 2-4 and 7) and one of the patterns with mixed electropherotype (lane 8).

Subgroup (SG) II strains were identified in 26 samples $(50.0 \%)$, all except one showing "long" electropherotypes. For two samples electrophoretic profile was not determined (Table 2). SG I specificity was found in 22 (42.3\%) strains: one strain with "long" electropherotype; $13(7.7 \%)$ strains with "short" electropherotypes and 8 $(15.4 \%)$ with the unusual electropherotype. Four specimens reacted with the group A-specific monoclonal antibody but did not show reactivity with any of the subgroup-specific monoclonal antibodies and were considered SG nonI-nonII (Table 2).

G2 serotype was shown as the only serotype in 32 $(59.3 \%)$ samples. Two samples had mixtures of G1+G2. G1 serotype was found in 18 (33.3\%) of strains alone and in three samples combined with $\mathrm{G} 2$ or G3 (Table 2). One sample reacted with group MAbs and did not react with serotype specific MAbs (Table 2).

In total, 52 strains were G genotyped with VP7 specific primer by RT-PCR. Genotype G2 was found as the only genotype in $23(42.6 \%)$ samples, and was also observed in 14 mixtures of genotypes (Tables 3 and 4). Thus, G2 genotype was the most frequent genotype and was identified in a total of 37 samples (Table 3).

Genotype G1 strains were detected as single genotype in $7(13.0 \%)$ samples and mixed with other genotypes in eight samples (Tables 3 and 4). G3 genotype was the only one found in one sample and in 2 other samples it was detected as mixtures. Genotype G4 strains were also detected in one case of single infection and in 8 mixed infections (Table 3 and 4). G5, G6 and G9 genotypes were found only in mixtures of genotypes (Table 3). A total of 20/52 (38.5\%) samples were characterized as mixed genotypes (Table 4).

All rotavirus positive strains were characterized for $\mathrm{P}$ genotypes. Genotype P[4] was found in 19 (35.2\%) samples alone, and in 11 samples with mixed infections (Tables 3 and 4). P[8] was found in 16 (29.6\%) samples alone and in 12 mixed infections. P[6-M37 like] was found in 3 samples alone and in 9 samples with mixed infections. P[6-Gottfried like] was not found alone, but was found in 6 samples with mixed $\mathrm{P}$ genotypes.
Table 1. Distribution of rotavirus infection by age group in children in São Paulo, Brazil, 1994-1995

\begin{tabular}{cccc}
\hline Age Group & \multicolumn{3}{c}{ Number of cases } \\
\cline { 2 - 4 }$($ Mo $)$ & Positive & Total & $\%$ \\
\hline $0-1$ & 0 & 11 & 0 \\
$2-6$ & 13 & 42 & 31,0 \\
$7-12$ & 13 & 35 & 37,1 \\
$13-24$ & 5 & 17 & 29,4 \\
$>25$ & 1 & 6 & 16,7 \\
\hline Total & 32 & 111 & 28,8 \\
\hline
\end{tabular}

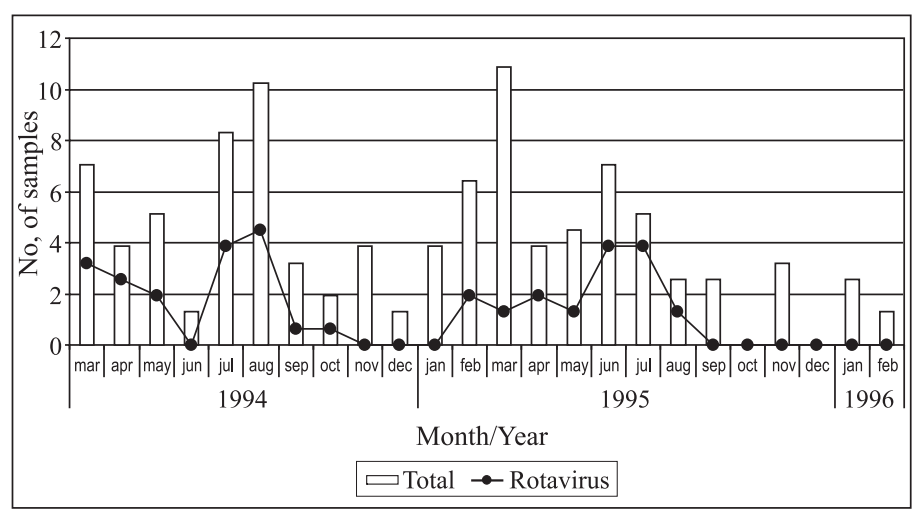

Figure 1. Temporal distribution of total numbers of fecal samples and numbers of rotavirus-positive strains by month of samples collection. All samples were collected in São Paulo, Brazil, 19941995.

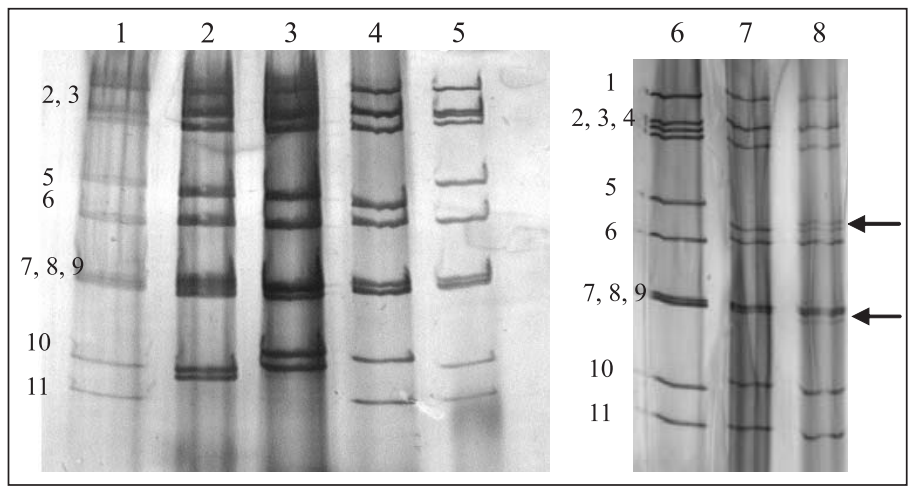

Figure 2. Polyacrylamide gel electrophoresis of representative strains of rotavirus from São Paulo Brazil. Lanes 1, 5 and 6: positive control (SiRV-A/SA11); lanes 2: strain ICB1375, unusual electropherotype; lane 3: strain ICB410, "short" electropherotype; line 4, strain ICB1410, "long" electropherotype; lane 7 strain ICB1340, "long" electropherotype; lane 8 strain ICB1343, "long" electropherotype, mixture of electropherotypes, extra segments indicated. 
Table 2. Serotype, subgroup and electrophoretic patterns of 54 rotavirus samples obtained from children from São Paulo, Brazil, 1994-1995.

\begin{tabular}{|c|c|c|c|c|c|c|c|}
\hline \multirow{2}{*}{$\begin{array}{c}\text { PAGE } \\
\text { (no of samples) }\end{array}$} & \multirow{2}{*}{ Subgroup } & \multicolumn{5}{|c|}{ G serotype } & \multirow{2}{*}{ Subtotal } \\
\hline & & G1 & G2 & G1+G2 & G1+G3 & Gneg & \\
\hline Long & I & & & & 1 & & 1 \\
\hline (24) & II & 13 & $10^{*}$ & & & & 23 \\
\hline & nonI-nonII & & & & & & 0 \\
\hline Short & I & 1 & 11 & 1 & & & 13 \\
\hline \multirow{3}{*}{ (17) } & II & & 1 & & & & 1 \\
\hline & nonI-nonII & 1 & & & & & 1 \\
\hline & NT & & 2 & & & & 2 \\
\hline Unusual & I & 1 & 7 & & & & 8 \\
\hline \multirow[t]{2}{*}{ (9) } & II & & & & & & 0 \\
\hline & nonI-nonII & & 1 & & & & 1 \\
\hline Neg & I & & & & & & 0 \\
\hline \multirow{2}{*}{ (4) } & II & 2 & & & & & 2 \\
\hline & nonI-nonII & & & 1 & & 1 & 2 \\
\hline $\begin{array}{l}\text { Total } \\
\text { (54) }\end{array}$ & & 18 & 32 & 2 & 1 & 1 & 54 \\
\hline
\end{tabular}

* includes 3 samples containing more than 11 dsRNA segments.

Table 3. Overall results of $G$ and $P$ genotyping of rotavirus strains circulating as single or mixed genotypes in São Paulo, Brazil, 1994-1995.

\begin{tabular}{lcccr}
\hline & \multicolumn{4}{c}{ No. of samples } \\
\cline { 2 - 5 } & Single & Mixture & \multicolumn{2}{c}{ Total } \\
\cline { 2 - 5 } GTYPE & & & $\mathbf{N}^{\mathbf{0}}$ & $\mathbf{\%}$ \\
\cline { 2 - 5 } G1 & & & & \\
G2 & 7 & 8 & 15 & 17.9 \\
G3 & 23 & 14 & 37 & 44.0 \\
G4 & 1 & 2 & 3 & 3.6 \\
G5 & 1 & 8 & 9 & 10.7 \\
G6 & 0 & 11 & 11 & 13.1 \\
G9 & 0 & 1 & 1 & 1.2 \\
Gneg & 0 & 6 & 6 & 7.1 \\
\hline Total & 2 & 0 & 2 & 2.4 \\
\hline PTYPE & $\mathbf{3 4}$ & $\mathbf{5 0}$ & $\mathbf{8 4}$ & $\mathbf{1 0 0 . 0}$ \\
P[4] & 19 & 11 & 30 & 39.0 \\
P[6-M37 like] & 3 & 9 & 12 & 15.6 \\
P[6-Gottfried] & 0 & 6 & 6 & 7.8 \\
P[8] & 16 & 12 & 28 & 36.4 \\
P[11] & 0 & 1 & 1 & 1.3 \\
\hline Total & $\mathbf{3 8}$ & $\mathbf{3 9}$ & $\mathbf{7 7}$ & $\mathbf{1 0 0 . 0}$ \\
\hline
\end{tabular}

$\mathrm{P}[8]$ genotype was detected mostly associated with G1 and P[4] was detected mostly in combination with $\mathrm{G} 2$ rotaviruses (Table 4). From three samples characterized as P[6-M37 like], one was associated with G2 genotype and two with mixtures of $G$ genotypes (Table 4). Mixtures of different $P$ types were found in 16 (29.6\%) samples (Table 4).

\section{DISCUSSION}

In 2005, two live oral rotavirus vaccines have been licensed and are available in some countries: a monovalent P[8]G1 vaccine (Rotarix ${ }^{\circledR}$, GlaxoSmithKline) and a pentavalent G1, G2, G3, G4 and P[8] vaccine (Rotateq ${ }^{\circledR}$, Merck Sharp \& Dohme). Both vaccines have shown efficacy against severe rotavirus disease $(17,43)$. The live, attenuated P[8]G1 human rotavirus vaccine was licensed in August 2005, and Brazil was the first country to introduce this vaccine for use in the public health network. Studies on rotavirus surveillance are very important to evaluate previous and current strains circulating in different regions, in order to assess the efficacy of the vaccines. The objectives of the present study were to characterize rotavirus strains circulating in São Paulo, Brazil, from March 1994 to February 1996.

We detected 54 positive samples of group A rotavirus (HRVA) from 157 (34.4\%) samples from children with gastroenteritis. No rotavirus was detected in children without diarrhea and no non-group A rotavirus was found. This result is similar to previous studies in Brazil, in which rotavirus positive samples were found in 12 to $42 \%$ of samples tested $(6,7,8,25)$. Recent studies in the same region of Brazil found 18-25\% positive for rotavirus $(7,8,10)$. This is also comparable to results obtained in other Latin American countries: in Paraguay, Chile and Venezuela $36 \%, 39 \%$ and $34 \%$ of outpatients were positive for rotavirus. (11,31).

In Brazil, a continental country, there are different seasonal patterns of rotavirus infection, depending on the region climate (25). In the North and Northeast regions, rotavirus infection occurs during all months. In the South, Southeast and Central West regions higher frequency of rotavirus infections are found in dryer months (May to September) (25). This seasonal characteristic was also shown in our data. In São Paulo, almost no positive HRV-A samples were found during the summer months and rotavirus frequencies showed a peak in the cooler months of both years (Fig. 1). This was also observed before in São Paulo (8), and in other South American countries, with temperate climate, like Paraguay and Argentina $(4,11)$. 
Table 4. Overall results of RT-PCR genotyping of rotavirus strains circulating in São Paulo, Brazil from 1994 to 1996.

\begin{tabular}{|c|c|c|c|c|c|c|c|c|c|c|c|c|}
\hline \multirow[b]{2}{*}{ Ggenotype } & \multicolumn{12}{|c|}{ No. of samples with P genotypes } \\
\hline & [4] & {$[6 \mathrm{M}]$} & {$[8]$} & $\begin{array}{l}{[4]+} \\
{[6 \mathrm{M}]}\end{array}$ & $\begin{array}{c}{[4]+} \\
{[8]}\end{array}$ & $\begin{array}{c}{[6 \mathrm{M}]+} \\
{[6 \mathrm{G}]}\end{array}$ & $\begin{array}{l}{[8]+} \\
{[6 G]}\end{array}$ & $\begin{array}{c}{[4]+} \\
{[6 \mathrm{M}]+} \\
{[8]}\end{array}$ & $\begin{array}{l}{[4]+} \\
{[8]+} \\
{[11]}\end{array}$ & $\begin{array}{c}{[4]+} \\
{[6 \mathrm{M}]+} \\
{[6 \mathrm{G}]+} \\
{[8]}\end{array}$ & Total & $\%$ \\
\hline 1 & & & 5 & & 1 & & & & & 1 & 7 & 13.0 \\
\hline 2 & 17 & 1 & & & 1 & 3 & 1 & & & & 23 & 42.6 \\
\hline 3 & & & & & & & & 1 & & & 1 & 1.9 \\
\hline 4 & & & 1 & & & & & & & & 1 & 1.9 \\
\hline $1+2$ & & & 1 & & & & & & & & 1 & 1.9 \\
\hline $1+4$ & & & 1 & & & & & & & & 1 & 1.9 \\
\hline $1+5$ & 1 & & 1 & & & & & & & & 2 & 3.7 \\
\hline $2+5$ & & & 1 & 1 & & & 1 & 1 & 1 & & 5 & 9.3 \\
\hline $2+6$ & 1 & & & & & & & & & & 1 & 1.9 \\
\hline $2+9$ & & 1 & & & & & & & & & 1 & 1.9 \\
\hline $4+9$ & & & 1 & & 1 & & & & & & 2 & 3.7 \\
\hline $1+2+3$ & & & 1 & & 1 & & & & & & 2 & 3.7 \\
\hline $2+4+5$ & & & & & & & & 2 & & & 2 & 3.7 \\
\hline $4+5+9$ & & 1 & & & & & & & & & 1 & 1.9 \\
\hline $1+2+4+9$ & & & 1 & & & & & & & & 1 & 1.9 \\
\hline $1+2+4+5+9$ & & & 1 & & & & & & & & 1 & 1.9 \\
\hline $\mathrm{Neg}$ & & & 2 & & & & & & & & 2 & 3.7 \\
\hline Total & 19 & 3 & 16 & 1 & 4 & 3 & 2 & 4 & 1 & 1 & 54 & 100.0 \\
\hline
\end{tabular}

P[6G], Gottfried-like; P[6M], M37-like; neg, negative.

In 111 children with available age data rotavirus infection was detected mainly in those 2 to 24 months of age (33.0\%), with a higher incidence (37.1\%) in children 6 to 12 months of age. These results were also shown in several regions of the world, as North of Africa (40), Europe (39), Latin America $(4,11,34)$, USA (16) and also in several Brazilian regions $(6,7,28,37)$.

Six different types of electrophoretic profiles of HRV-A (data not shown) show different viral strains circulating at the same time in São Paulo. This result was also reported for other Brazilian regions: North $(28,30)$, Central $(5)$ and Southeast $(7,37)$ as well in other parts of the world $(3,11,42)$. Three samples with more than 11 dsRNA segments were also found, showing a mixed infection with two different rotavirus strains. These samples presented also multiple serotypes and genotypes. This mixture of genotypes was also found in other parts of Brazil (30). This double infection can lead to reassortment of dsRNA segments and appearance of other serotypes/genotypes.

By using a monoclonal double-antibody sandwich ELISA, the subgroup specificities of 52/54 (96.3\%) rotavirus-positive stool samples tested in this study were determined. Among them, the frequency of subgroup Il samples was $50.0 \%$, compared with $42.3 \%$ for subgroup I and $7.7 \%$ for subgroup nonI-nonII (Table 2). The predominance of subgroup II over subgroup I was also found in a previous study in São Paulo (7).

A good correlation was found between subgroup specificity and pattern of electropherotypes. We found the majority of short PAGE profiles combined with subgroup I, as expected; only one sample did not present this characteristic. Also, most of the long profile rotavirus were associated with subgroup II, and only one sample was SG I (24). Eight samples with unusual electrophoretic profiles were subgroup I, and one sample SG nonI-nonII; all samples belonged to genotype G2P[4] (data not shown): this is an indication that this unusual PAGE pattern, described but not characterized for $\mathrm{G}$ and $\mathrm{P}$ before in Brazil $(7,28)$ could be originated from short profile HRV-A, with a change of mobility in segments 10 and/or 11. Nevertheless, further studies are necessary to confirm this hypothesis.

Serological and molecular characterization of HRV-A VP7 and VP4 specificity has been investigated all over the world, due to the immunogenic properties of these proteins, relevant for any vaccination efficiency (15). The present study showed co-circulation of several serotypes and genotypes in a two year period. 
Only one sample was not characterized for G serotype by the MAbs utilized. Serotype G2 was shown as the only serotype in the majority of the samples $(32 / 54,59.3 \%)$. Also, two samples were shown with mixtures of G1+G2. G1 serotype was found in 18 strains alone and in 3 samples combined with G2 or G3 (Table 2 ). This was the only G3 sample we found in this work, and this result was also confirmed by genotyping. In the Central Region of Brazil, HRV-A serotyped between 1990 and 1993 had G2 as the major serotype. G1 genotypes were not found between 1990 and 1992, but reappeared in 1993. G2 was still the most frequent in 1993 but in 1994, G1 became the major serotype (5). In our results, G1 and G2 were found co-circulating in 1994 and 1995, with G2 being the most frequent serotype. In Argentina, our neighbor country, G2 was also the most frequent between 1995 and 1996 (13). Several authors suggest that the serotype prevalence for a region could change from year to year, in a situation similar to the worldwide infection with influenza virus, which also have a segmented genome $(3,5,25)$.

Ten samples with long electropherotypes were characterized as serotype G2, an unusual association. All were associated with $\mathrm{P}[8]$ genotype, alone or in mixtures (data not shown). This result was also reported in other Brazilian regions (25) and in North of Africa (2).

From the 54 strains, only 2 were not typed for G genotype and all of them were characterized for P genotype. G2 genotype was the most frequently found (44.0\%), alone (62.2\%) or mixed with other genotypes (37.8\%), followed by G1 (17.9\%), alone $(46.6 \%)$ or in mixtures $(53.4 \%)$. This result confirms the conclusion from Jain et al., in India, where it was found that, compared with non serotype G2 strains, serotype G2 strains were found more frequently in infections caused by single RV serotype strains than in mixed infections (23).

G3 and G4 were only found alone in one sample each. G5, G6 and G9 were only found in mixtures with other genotypes. Cocirculation of several genotypes was reported by authors in Brazil $(7,8)$, and in other countries as Venezuela (34), Australia (3) and India (23).

G9 genotype, considered as emerging in several countries, was found only associated with other genotypes in our samples. Authors reported that G9 was found in Brazil since 1997 (8). With our present results, we were able to further expand the detection of G9 since 1994. According to Carmona et al. (8) G9 displaced G1 genotypes in São Paulo, Brazil in 2002. G9 has become the fifth most common serotype worldwide, and should be considered for inclusion in the vaccination programs (10).

G5 genotype, normally associated with porcine diarrhea, has been frequently found in children in Brazil, from 1982 to 1997 $(7,20,38)$. We detected 11 samples with G5 in mixtures with other genotypes, which corroborate the importance of this genotype in 1994-1996 seasons in Brazil, accounting for 13.1\% of samples.

We found 20/54 (38.5\%) of G and P mixed types in our samples. In Latin America, percentages from 0 to $44.1 \%$ were found in several locations in Brazil, including São Paulo $(7,8)$ and in several Latin American countries (38). Mixed infections provide an opportunity for human rotavirus to evolve by reassortment, mediated infection of the same gut cell with two different viruses $(9,10)$. The detection of G2P[8] strains with long RNA profile in PAGE is a strong indication that reassortment of rotavirus has already occurred.

All strain were characterized for P genotypes. P[4] was found in 19 samples alone and 11 samples in mixed genotypes, or in $55.6 \%$ of all the samples, mostly associated with G2, alone or in mixtures. P[8] was found in 28/54 (51.9\%), mostly associated with G1, G5 and G9. P[4] and P[8] strains were the most common strain detected in Brazil since $1982(7,8,38)$ and our data confirm this finding. P[6-M37 like] was the third most frequently found, in 12/54 (22.3\%) samples. This strain was detected before in several countries, including Brazil $(7,8,26)$. In our data, P[6-M37 like] was associated with G2 alone, and with G1, G3, G4, G5, G9 in mixtures (Table 4), as in most parts of the world $(38,41)$.

Our genotyping system differentiates human P[6-M37 like] and animal P[6-Gottfried like], similar to the porcine Gottfried strain (35). We only found P[6-Gottfried like] in mixtures with other P genotypes. The origin of this porcine genotype could be the same as the G5 porcine strains found in Brazil at the same time.

We also found, for the first time in Latin America, one sample with G6 specificity, mixed with a G2 rotavirus and one P[11] strain, mixed with P[4] and P[8]. G6 and P[11] are frequently found in cattle (24). G6 rotaviruses were recently found in 7.1\% of human samples in Hungary (1), but so far, rotavirus strains bearing the $\mathrm{P}[11]$ specificity have not been detected in humans outside of India until now (38). Detection of animal-like rotavirus strains, mixed with human genotypes, suggests the possibility for natural human-animal genetic reassortment.

This diversity of rotavirus strains we described here is characteristic of developing countries and is distinct from the observations in more developed countries like USA, where mixed infections and unusual strains are rarely found. These differences may be originated by exposure of larger and more diverse inoculum of rotavirus from food or water obtained in fecally contamined environments (23). This diversity could reflect in differences in rotavirus epidemiology as well as in the efficacy of vaccines used in our country. Continuous surveillance should be implemented for documentation of the degree of diversity, after the introduction on the public health system of a monovalent vaccine, which was already done in Brazil.

\section{ACKNOWLEDGMENTS}

This work was supported by FAPESP grants 1999/04575-9 and 2001/07298-8. M.L. Rácz has a CNPq scholarship. T.A.R. Caruzo had a FAPESP PhD scholarship. 


\section{RESUMO}

\section{Diversidade sorológica e molecular de rotavírus identificados em crianças em São Paulo, Brasil}

De um total de 187 amostras fecais de crianças com idades entre 0 e 5 anos, coletadas no Hospital Universitário -USP, Brasil, de 1994 a 1996, 54 (28.9\%) foram positivas para rotavírus. As amostras positivas foram caracterizadas quanto ao eletroferótipo, subgrupo, sorotipo G e genotipo G e P. Foram identificados quatro diferentes eletroferótipo longos em $38.9 \%$ das amostras, um eletroferótipo curto $(34,0 \%)$ e $18,0 \%$ foram caracterizadas como um eletroferótipo não usual. O subgrupo I foi encontrado em $38,9 \%$ amostras, o subgrupo II em 50,0\% e nãoI-nãoII em 7,7\%. O sorotipo G2 foi encontrado em 59,3\% e $\mathrm{G} 1 \mathrm{em} 33,3 \%$. Duas amostras apresentaram misturas de G1+G2 e outra amostra G1+G3. Dez amostras caracterizadas como sorotipo G2 mostraram perfil eletroferótico longo. O genotipo G2 foi o mais freqüente, encontrado em 37 amostras (23 como único genotipo e 14 associados a outro genotipo). G1 foi encontrado em 15 amostras; G3 e G4 foram detectados principalmente em misturas e G5, G6 e G9, identificados somente em misturas. Um total de $20(38,5 \%)$ amostras foram identificadas como misturas de genotipo $\mathrm{G}$ e foram encontradas $16(29,6 \%)$ amostras com misturas de genotipo P. P[4] foi encontrado em $55,6 \%$ das amostras, $\mathrm{P}[8]$ em $51,9 \%$ e $\mathrm{P}[6-\mathrm{M} 37$ like $]$, em 5,5\% das amostras. P[6-Gottfried like] e P[11] foram detectados somente em misturas. Uma amostra com especificidade G6, associada ao genotipo G2 e outra P[11] misturada com P[4] e de P[8] foram identificadas pela primeira vez na América Latina.

Palavras chave: rotavírus, gastroenterites, PCR, sorotipos, genotipos.

\section{REFERENCES}

1. Bányai; K.; Gentsch, J.; Glass, R.I.; Mihály, M.Ú.I.; Szucs, G. (2004). Eight-year survey of human rotavirus strains demonstrates circulation of unusual G and P types in Hungary. J. Clin. Microbiol., 42(1), 393397.

2. Bingnan, F.; Unicomb, L.E.; Guangli, T.; Malek, A.A.A.; Rahim, Z.; Tzipori, S. (1991). Cultivation and characterization of novel human group A rotaviruses with long RNA electropherotypes, subgroup II specificities and serotype 2 VP7 gene. J. Clin. Microbiol., 29(10), 2224-2227.

3. Bishop, R.F.; Masendycz, P.J.; Bugg, H;C;; Carlin, J.B.; Barnes, G.L. (2001). Epidemiological patterns of rotaviruses causing severe gastroenteritis in young children throughout Australia from 1993 to 1996. J. Clin. Microbiol., 39(3), 1085-1091.

4. Bok, K.; Castagnaro, N.; Borsa, A.; Nates S.; Espul, C.; Fay, O.; Fabri, A.; Grinstein, S.; Miceli, I.; Matson, D.O; Gómez, J.A. (2001). Surveillance for rotavirus in Argentina. J. Med. Virol., 65, 190-198.

5. Cardoso, D.D.P.; Soares, C.M.A.; Azevedo, M.S.P.; Leite, J.P.G.; Munford, V.; Rácz, M.L. (2000). Serotypes and subgroups of rotavirus isolated from children in Central Brazil. J. Health. Popul. Nutr. 18(1), 39-43.
6. Cardoso, D.D.P.; Soares, C.M.A.; Souza, M.B.L.D.; Azevedo, M.S.P.; Martins, R.M.B.; Queróz, D.A.O.; Brito, W.M.E.D.; Munford, V.; Rácz, M.L. (2003). Epidemiological features of rotavirus infection in Goiânia; Goiás; Brazil from 1986 to 2000. Mem. Inst. Oswaldo Cruz., 98(1), 25-29.

7. Carmona, R.C.C.; Timenetsky, M.C.S.T.; Silva, F.F.; Granto, C.F.H (2004). Characterization of rotavírus strains from hospitalized and outpatient children with acute diarrhoea in São Paulo; Brazil. $J$. Med. Virol., 74, 166-172.

8. Carmona, R.C.C.; Timenetsky, M.C.S.T.; Morillo, S.G.; Richtzenhain, L.J. (2006). Human rotavirus serotype G9; São Paulo; Brazil; 19962003. Emerging Infect. Dis., 12(6), 963-968.

9. Castello, A.A.; Argüelles, M.H.; Rota, R.P.; Olthoff, A.; Jiang, B.; Glass, R.I.; Gentsch, J.R.; Glikmann, G. (2006). Molecular epidemiology of group A rotavírus diarrhea among children in Buenos Aires; Argentina; from 1999 to 2003 and emergence of the infrequent genotype G12. J. Clin. Microbiol., 44(6), 2046-2050.

10. Castello. A.; Arvay, M.L.; Glass, R.I.; Gentsch, J. (2004). Rotavirus strain surveillance in Latin America: a review of last nine years. Pediatr. Infect. Dis. J., 23(10), S168-S172.

11. Coluchi, N.; Munford, V.; Manzur, J. ; Vazquez, C.; Escobar, M.; Weber, E.; Mármol, P.; Rácz, M.L. (2002). Detection; subgroup specificity and genotype diversity of rotavirus strains in children with acute diarrhea in Paraguay. J. Clin. Microbiol., 40(5),17091714.

12. Das, B.K.; Gentsch, J.R.; Cicirello, H.G.; Woods, P.A.; Gupta, A.; Ramachandran, M.; Kumar, R.; Bhan, M.K.; Glass, R.I. (1994). Characterization of rotavirus strain from newborns in New Delhi; India. J. Clin. Microbiol., 32(7), 1820-1822.

13. Espul, C.; Cuello, H.; Martinez, N.; Centorbi, O.; O'ryan, M.; Jackson, L.; Campos, F.; Matson, D.O. (2000). Genomic and antigenic variation among rotavirus strains in a large city of Argentina. $J$. Med. Virol., 61, 504-509.

14. Gentsch, J.R.; Glass, R.I.; Woods, P.; Gouvea, V.; Gorziglia, M.; Flores, J.; Bimal, K.D.; Bhan, M.K. (1992). Identification of group A rotavirus gene 4 types by polymerase chain reaction. J. Clin. Microbiol. 30(6), 1365-1373.

15. Gentsch, J.R.; Wood, P.A.; Ramachandran, M.; Das, B.K.; Leite, J.P.; Alfieri, A.A.; Kumar, R.; Bhan, M.K.; Glass; R.I. (1996) Review of $\mathrm{G}$ and $\mathrm{P}$ typing results from a global collection of rotavirus strains: implications for vaccine development. J. Infect. Dis., 174(suppl 1), S30-36.

16. Glass, R.I.; Kilgore, P.E.; Holman, R.C.; Jin, S.; Smith, J.C.; Woods, P.A.; Clarke, M.J.; Ho, M.S.; Gentsch, J.R. (1996). The epidemiology of rotavirus diarrhea in the United States: surveillance and estimates of Disease Burden. J. Infect. Dis., 174(suppl 1), S5-11.

17. Glass, R.I.; Parashar, U.D. (2006). The promise of new rotavirus vaccines. N. Engl. J. Med. 354, 75-77.

18. Gouvea, V.; Santos, N.; Timenetsky. M.C. (1994). Identification of bovine and porcine rotavirus G types by PCR. J. Clin. Microbiol. 32(5), 1338-1340.

19. Gouvea, V.; Santos, N.; Timenetsky. M.C. (1994). VP4 typing of bovine and porcine group A rotaviruses by PCR. J. Clin. Microbiol., 32(5), 1333-1337.

20. Gouvea V; Castro L; Timenetsky MC; Greenberg HB; Santos N (1994) Rotavirus serotype G5 associated with diarrhea in Brazilian children. J. Clin. Microbiol., 32(5), 1408-1409.

21. Greenberg, H.; McAuliffe, V.; Valdesuso, J.; Wyatt, R.; Flores, J.; Kalica, A.; Hoshino, Y.; Singh, N. (1983). Serological analysis of the subgroup protein of rotavirus using monoclonal antibodies. Infect. Immun., 39(1), 91-99.

22. Herring, A.J.; Inglis, N.F.; Ojeh, C.K.; Snodgrass, D.R.; Menzies, J.D. (1982). Rapid diagnosis of rotavirus infection by direct detection of viral nucleic acid in silver-stained polyacrylamide gels. J. Clin. Microbiol., 16(3), 473-477. 
23. Jain, V.; Das, B.K.; Bhan, M.K.; Glass, R.I.; Gentsch, J,R.; The Indian strains surveillance collaborating laboratories. (2001). Great diversity of group A rotavirus strains and high prevalence of mixed rotavirus infection in India. J. Clin. Microbiol., 39(10), 3524-3529.

24. Kapikian, A. Z.; Hoshino, Y.; Chanock, R. M. (2001). Rotaviruses. In D. M. Knipe and P. M. Howley (eds). Fields Virology. Lippincott Williams \& Wilkins, Philadelphia, USA. p.1787-1833.

25. Linhares, A.C. (2000). Epidemiologia das infecções por rotavírus no Brasil e os desafios para o seu controle. Cad. Saúde. Pública. 16(3), 629-646.

26. Linhares, A.C.; Mascarenhas, J.D.P.; Gusmão, R.H.P.; Gabbay, Y.B.; Fialho, A.M.; Leite, J.P. (2002). Neonatal rotavírus infection in Belém, norther Brazil: Nosocomial transmission of P[6]G2 strain. J. Med. Virol., 67, 418-426.

27. Liprandi, F.; Lopez, G.R.; Hidalgo, M.; Ludert, J.E.; Mattion, N. (1990). Monoclonal antibodies to the VP6 of porcine subgroup I rotaviruses reactive with subgroup I and non-subgroup I non- subgroup II strains. J. Gen. Virol., 71, 1395-1398.

28. Luz, C.R.N.E.; Mascarenhas, J.D.P.; Gabbay, Y.B.; Motta, A.R.B.; Lima, R.T.V.; Soares, L.S.; Linhares, A.C. (2005). Rotavirus serotypes and electropherotypes identified among hospitalized children in São Luis, Maranhão, Brazil. Rev. Inst. Med. Trop. São Paulo, 47(5), 287-293.

29. Martella, V.; Ciarlet, M.; Banyai, K.; Lorusso, E.; Arista, S.; Lavazza, A.; Pezzotti, G.; Decaro, N.; Cavalli, A.; Lucente, M.S.; Corrente, M.; Elia, G.; Camero, M.; Tempesta, M.; Buonavoglia, C. (2006). Identification of group A porcine rotavirus strains bearing a novel VP4 (P) genotype in Italian swine herds. J. Clin. Microbiol, In Press.

30. Mascarenhas, J.D.P.; Gusmão, R.H.P.; Gabbay, Y.B.; Monteiro, T.A.F.; Gomes, B.R.; Linhares, A.C. (1996). Concomitant rotavirus serotypes 1 and 4 infections a diarrheic child from Belém, Brazil. Rev. Inst. Med. Trop. São Paulo, 38(4), 249-252.

31. O'Ryan, M.; Perez-Schael, I.; Mamani, N.; Pena, A.; Salinas, B.; Gonzalez, G.; Gonzalez, F.; Matson, D.; Gomez, J. (2001). Rotavirusassociated medical visits and hospitalizations in South America: a prospective study at three large sentinel hospitals. Pediatr. Infect. Dis. J., 20(7), 685-693.

32. Pereira, H.G.; Azeredo, R.S.; Leite, J.P.G.; Andrade, Z.P.; Castro, L. (1985) A combined enzyme immunoassay for rotavirus and adenovirus. J. Virol. Meth., 10, 21-28.

33. Pereira, H.G.; Azeredo, R.S.; Leite, J.P.G.; Candeias, J.A.N.; Rácz, M.L.; Linhares, A.C.; Gabbay, Y.B.; Trabulsi, L.R. (1983). Electrophoretic study of the genome of human rotaviruses from Rio de Janeiro, São Paulo and Pará, Brazil. J. Hyg. Camb., 90, 117125 .
34. Pérez-Schael, I.; González, R.; Fernández, R.; Alfonso, E.; Inaty D.; Boher, Y.; Sarmiento, L. (1999). Epidemiological features of rotavirus infection in Caracas, Venezuela: implications for rotavirus immunization programs. J. Med. Virol., 59, 520-526.

35. Rácz, M.L.; Kroeff, S.S.; Munford, V.; Caruzo, T.A.R.; Durigon, E.L.; Hayashi, Y.; Gouvea, V.; Palombo, E.A. (2000). Molecular characterization of porcine rotaviruses from the southern region of Brazil: characterization of an atypical genotype G9 strain. J. Clin. Microbiol., 38(6), 2443-2446.

36. Rácz, M.L.; Munford, V.; Fernandes, M.J.B.; Kroeff, S.S.; Kotait, I. (1993). Identification, propagation and subgroup characterization of an equine rotavirus isolated in Sao Paulo, Brazil. Rev. Microbiol. São Paulo, 24(3), 161-165.

37. Rosa e Silva, M.L.; Carvalho, I.P.; Gouvea, V. (2002). 1998-1999 rotavirus seasons in Juiz de Fora, Minas Gerais, Brazil: Detection of unusual G3P[4] epidemic strain. J. Clin. Microbiol., 40(8), 28372842.

38. Santos, N.; Hoshino, Y. (2005) Global distribution of rotavirus serotypes/genotypes and its implication for the development and implementation of an effective rotavirus vaccine. Rev. Med. Virol., $15,29-56$

39. Sánchez-Fauquier, A.; Wilhelmi, I.; Colomina, J. Cubero, E.; Roman, E. (2004). Diversity of group A human rotavirus type circulating over a 4 year period in Madrid, Spain. J. Clin. Microbiol., 42(4), 1609-1613.

40. Trabelsi, A.; Peenze, I.; Pager, C.; Jeddi, M.; Steele, D. (2000). Distribution of rotavirus VP7 serotypes and VP4 genotypes circulating in Sousse, Tunisia, from 1995 to 1999: emergence of natural human reassortants. J. Clin. Microbiol., 38(9), 3415-3419.

41. Uchida, R.; Pandey, B.D.; Sherchand, J.B.; Ahmed, K.; Yokoo, M.; Nakagomi, T.; Cuevas, L.E.; Cunliffe, N.A.; Hart, C.A.; Nakagomi, O. (2006). Molecular epidemiology of rotavírus diarrhea among children and adults in Nepal: detection of G12 strains with P[6] or $\mathrm{P}[8]$ and G11P[25] strain. J. Clin. Microbiol., 44(10), 3499-3505.

42. Van der Heide, R.; Koopmans, M.P.G.; Shekary, N.; Houwers, D.J.; Van Duynhoven, Y.T.H.P.; Van der Poel, W.H.M. (2005). Molecular characterizations of human and animal group A rotaviruses in the Netherlands. J. Clin. Microbiol., 43(2), 669-675.

43. Vesikari, T.; Matson, D.O.; Dennehy, P.; Van Damme, P.; Santosham, M.; Rodriguez, Z.; Dallas, M.J.; Heyse, J.F.; Goveia, M.G.; Black, S.B.; Shinefield, H.R.; Christie, C.D.C.; Ylitalo, S.; Itzler, R.F.; Coia, M.L.; Onorato, M.T.; Adeyi, B.A.; Marshall, G.S.; Gothefors, L.; Campens, D.; Karvonen, A.; Watt, J.P.; O’Brien, K.L.; DiNubile, M.J.; Clark, H.F.; Boslego, J.W.; Offit, P.A.; Heaton, P.M. (2006). Safety and efficacy of a pentavalent human - bovine (WC3) reassortant rotavirus vaccine. N. Engl. J. Med., 354, 23-33. 